\title{
CIÚME, EXÍlIO E POESIA EM MACHADO DE ASSIS
}

\section{JEALOUSY, EXILE AND POETRY IN MACHADO DE ASSIS}

\author{
Rogério Fernandes dos SANTOS ${ }^{1}$
}

\begin{abstract}
Resumo: Segundo Silviano Santiago, a obra romanesca de Machado de Assis, em sua série cronológica, possui "certas estruturas primárias e primeiras [que] se desarticulam e se rearticulam sob a forma de estruturas diferentes, mais complexas e sofisticadas". O estudo do ciúme enquanto expressão patriarcal na cultura brasileira é uma dessas estruturas que o crítico estudou para compreender o romance machadiano. O presente artigo busca levar adiante as formulações de Santiago, inserindo no debate questões como exílio, ciúme e espaço social como parte do repertório estrutural do romance machadiano. Para tanto, analisa episódios em que esses temas estão presentes em Helena (1876), A mão e a luva (1874) e, sobretudo, Dom Casmurro (1899).
\end{abstract}

Palavras-chave: Machado de Assis. Romance Brasileiro. Espaços Sociais. Literatura Comparada. Literatura Brasileira.

Abstract: According to Silviano Santiago, the romanesque work of Machado de Assis, in its chronological series, has "certain primary and early structures [which] are disjointed and rearticulated into different, more complex and sophisticated structures." The study of jealousy as a patriarchal expression in Brazilian culture is one of those structures that the Santiago studied to understand Machado's novel. This paper seeks to advance Santiago's formulations by including in the debate issues such as exile, jealousy and social space as part of the structural repertoire of Machado's novel. For this purpose, an analyses is carried out on episodes in which these themes are present in Helena (1876), A mão e a luva (1874) and Dom Casmurro (1899).

Keywords: Machado de Assis. Brazilian Novel. Comparative Literature. Social Spaces. Brazilian Literature.

Um dos momentos de renovação da leitura de Dom Casmurro (1899) ocorreu em 1969. Nesse ano, o professor e ensaísta Silviano Santiago fez uma importante observação sobre a obra de Machado de Assis.

Já é tempo de se começar a compreender a obra de Machado de Assis como um todo coerentemente organizado, percebendo que à medida que seus textos se sucedem cronologicamente certas estruturas primárias e primeiras se desarticulam e se rearticulam sob a forma de estruturas diferentes, mais complexas e sofisticadas (SANTIAGO, 2000, p. 27).

\footnotetext{
${ }^{1}$ Professor substituto de Literaturas de Língua Portuguesa na UFRPE/UAST entre 2017 e 2018. r_fernandes_santos@yahoo.com.br Revista Graphos, vol. 21, n² 2, 2019 | UFPB/PPGL | ISSN 1516-1536
} 
Santiago trata especificamente dos romances de Machado de Assis, sugerindo que a série de nove romances escritos pelo escritor fluminense entre 1872 e 1908 é palco de temas estruturalmente elaborados em sua sucessão cronológica. O ensaísta não trata dos contos, poemas e peças teatrais, embora seja possível sugerir que o mesmo ocorra em todos os gêneros aos quais Machado se dedicou.

O primeiro romance, Ressurreição, escrito em 1872, é exemplo dessas reorganizações temáticas. Na trama, Félix não consegue lidar com a flecha do ciúme e da dúvida, renunciando ao amor da jovem viúva Lívia. O casamento e tudo o que o envolve em uma sociedade brutalmente patriarcal dita as ações do rapaz. "O problema do ciúme surgiu no universo machadiano [...] da concepção que têm os personagens machadianos do que seja o amor e o casamento" (SANTIAGO, 2000, p. 31). Segundo o crítico, a prosa de ficção machadiana concebe o amor como parte da instituição do casamento, com todas as suas prerrogativas materiais, propriedades, títulos e convenções.

Um dos efeitos dessa equação em um contexto notadamente patriarcal é o ciúme e a constante vigília masculina advinda desse sentimento. O modo como Machado reelabora esse tema ao longo de sua obra é um dos pontos centrais dos estudos machadianos. Disso resulta outra revisão importante feita por Silviano Santiago acerca de Dom Casmurro e que deve ser anotada. Dom Casmurro não é um romance, a exemplo de Madame Bovary e Primo Basílio, que busca fazer o estudo psicológico do adultério feminino. Não se trata de absolver ou condenar Capitu - uma disputa de leituras e interpretações apaixonadas que tomou conta da crítica machadiana por mais de meio século. Se estudo há, é o estudo sobre o ciúme e o modo como ele adere e mobiliza as estruturas históricas e sociais para justificar sua narrativa e sedimentar sua porosa obsessão.

Roberto Schwarz aponta que "os ciúmes condensam uma problemática social ampla, historicamente específica, e funcionam como convulsões da sociedade patriarcal em crise" (SCHWARZ, 1997, p. 11). Nesse sentido, o ciúme machadiano, uma relação de posse e poder nutrida pela patologia patriarcal, distancia-se da definição dada pela psicanálise. Para Melanie Klein,

Deve-se traçar uma distinção entre inveja, ciúme e voracidade. A inveja é o sentimento irado de que outra pessoa possui e desfruta de algo desejável - sendo o impulso invejoso tirá-lo dela ou espoliá-lo. Além disso, a inveja implica na relação do indivíduo apenas com uma só pessoa e remonta a mais primitiva relação exclusiva com a mãe. O ciúme se baseia na inveja, mas envolve uma relação com, pelo menos, duas pessoas; diz respeito principalmente ao amor que o indivíduo sente como lhe 
sendo devido e que lhe foi tirado ou se acha em perigo de sê-lo, por seu rival. Na concepção popular de ciúme, um homem ou uma mulher se sente despojado da pessoa amada por outrem (KLEIN, 1984, p. 29).

Aqui, é necessário um parêntese para reconhecer que a leitura empreendida por Helen Caldwell (2002), em O Otelo brasileiro de Machado de Assis, é responsável por colocar em dúvida o relato de Dom Casmurro. Caldwell (2002) parte de minucioso estudo sobre Otelo e o modo como a leitura da tragédia de Shakespeare é utilizada pelo narrador como argumento para as suas suspeitas. Trata-se de um estudo pioneiro que adverte o leitor brasileiro, imerso na estrutura patriarcal e escravista, de que a única voz que se manifesta no romance é a de Bento Santiago, imerso em mágoas e disposto a provar para si e para o leitor que o seu ocaso se origina na perfídia de Capitu, que não possui voz no romance. Não é exagero afirmar que o estudo de Caldwell (2002) foi um dos alicerces para a necessária revisão do estatuto do narrador nos romances de Machado. Uma abordagem muito influente e que rendeu comentários irônicos como o do crítico português Abel Barros Baptista, que, na melhor tradição da ironia machadiana, chamou a desconfiança em relação aos narradores de "paradigma do pé atrás". 2

Retomando Santiago, saliento que compreender os romances de Machado como um todo coeso não autoriza o erro de irmos aos primeiros romances para justificar o brilho de Memórias Póstumas de Brás Cubas, Dom Casmurro e demais romances da chamada "segunda fase" do autor. O que se propõe é entender a resposta dada por Machado às suas obsessões temáticas de acordo com o horizonte de expectativas e campo cultural em que cada obra se insere.

\section{O ciúme a retórica dos livros}

Aproveito para abrir uma pequena frente para dialogar com as "estruturas primárias e primeiras" da obra de Machado; o elemento retórico dos livros, como símbolo fetichizante e como elemento de construção metaficcional. Há, por toda a obra romanesca de Machado de Assis, esses livros, autores e personagens ficcionais da literatura ocidental que são reapresentados em contextos sociais e históricos diferentes a cada romance.

Como primeiro exemplo, vejamos como Otelo é referenciado em diferentes momentos. Em Helena, romance escrito em capítulos em 1876, Machado estava interessado em dialogar

\footnotetext{
${ }^{2} \mathrm{O}$ trabalho de Abel Barros Baptista representa saudável oxigenação no debate em torno da obra de Machado de Assis por reivindicar autonomia crítica e de leitura diante da obra machadiana. Consultar as indicações bibliográficas BAPTISTA (2003a) e (2003b).
}

Revista Graphos, vol. 21, n² 2, 2019 | UFPB/PPGL | ISSN 1516-1536 
com o grande público leitor de folhetins, romances seriados de ação e entrecho amoroso ${ }^{3}$, muito próximos do que são as nossas telenovelas. Na trama, Helena é filha da amante do conselheiro Vale, rico proprietário que morre repentinamente e reconhece Helena como filha em seu testamento. Obrigada a conviver com sua nova família, ela furtivamente visita seu pai biológico, Salvador, em uma pequena cabana no campo nos arredores da chácara da família Vale. Convidado a se explicar, Salvador relata seu relacionamento com Ângela, mãe de Helena. Diz ele:

\begin{abstract}
Poucos dias antes, a bordo, um engenheiro inglês que vinha do Rio Grande para esta Corte, emprestara-me um volume truncado de Shakespeare. Pouco me restava do pouco inglês que aprendi; fui soletrando como pude, e uma frase que ali achei fez-me estremecer, na ocasião, como uma profecia; recordei-a depois, quando Ângela me escreveu. "Ela enganou seu pai, diz Brabantio a Otelo, há de enganar-te a ti também". Era justo; pelo menos, era explicável (ASSIS, 1977c, p. 211).
\end{abstract}

Aqui, há uma dupla suspeita: a da traição de Ângela e do relato de Salvador. O narrador é digno de crédito? Quais interesses estão ocultos nas ações e fala desse narrador? A suspeita avança até em relação à leitura e à interpretação que esses narradores fazem de Otelo. Do volume "truncado" de Shakespeare, Salvador reteve apenas aquilo que ilustrava as suas suspeitas. Ao mesmo tempo em que equipara a sua experiência à de Otelo, o personagem-leitor extrai da obra apenas aquilo que convém a suas expectativas e situações, fazendo da literatura um instrumento retórico.

Essa passagem ilustra a rearticulação dos temas machadianos. Se, em Helena, o estudo do ciúme apresenta-se como exercício melodramático, em Dom Casmurro, ele assume proporções mais amplas, sintomáticas de seu tempo de crise do paternalismo, como estudo das instituições que se esgarçam tal a violência de suas práticas.

O conhecimento prévio do leitor acerca da peça da Tragédia de Otelo é a de que se trata de uma história de ciúmes e morte. O general mouro Otelo, instigado por Iago, estrangula a inocente Desdêmona. Assim, atributos como ciúme e morte são recortados do contexto da tragédia de Shakespeare e recondicionados na narrativa de Salvador, em Helena, e de Bento Santiago, em Dom Casmurro. Ocorre que esses narradores-atores, sujeitos de suas próprias narrativas, sobrepõem suas vozes à voz de Otelo, inserindo na trama um comentário que nos esclarece sobre a natureza da ficção romanesca. O diálogo entre vozes cujo discurso encontrase nos mais diferentes registros sociais e artísticos, formando uma estrutura de significados que

\footnotetext{
${ }^{3}$ Sobre as relações entre Helena e o romance folhetinesco e melodramático veja-se SANTOS (2009).

Revista Graphos, vol. 21, n² 2, 2019 | UFPB/PPGL | ISSN 1516-1536
} 
demanda interpretação e distanciamento crítico do leitor. Mas como manter o distanciamento diante de paixões como ciúme e morte, afetos que nos falam de perto?

Por conta dessas paixões contidas na primeira leitura é que o narrador de Dom Casmurro entrega ao leitor de antemão a chave interpretativa.

\footnotetext{
[...] não me pude furtar à observação de que um lenço bastou a acender os ciúmes de Otelo e compor a mais sublime tragédia deste mundo. [...] $\mathrm{O}$ último ato mostrou-me que não eu, mas Capitu devia morrer. Ouvi as súplicas de Desdêmona, as suas palavras amorosas e puras, e a fúria do mouro, e a morte que este lhe deu entre aplausos frenéticos do público.

- E era inocente, vinha eu dizendo rua abaixo; - que faria o público, se ela deveras fosse culpada, tão culpada como Capitu? E que morte lhe daria o mouro? Um travesseiro não bastaria; era preciso sangue e fogo [...] (ASSIS, 1977d, p. 244-245)
}

Se Desdêmona, que era inocente, foi morta, "o que faria o público, se ela fosse tão culpada quanto Capitu? [...] Sangue e fogo". Ao fazer de Otelo uma extensão de sua subjetividade, o narrador faz do intertexto um despiste do que deveria estar em primeiro plano, a obsessão de Bento Santiago em nos fazer crer que Capitu é culpada.

É importante destacar a radicalização do processo narrativo de Dom Casmurro. Quem escreve o romance não é o Bentinho, jovem apaixonado por sua fascinante vizinha Capitu, com quem viria a se casar e habitar a casa da infância e que veria, com o tempo, suas idealizações românticas ruírem. O autor ficcional é Dom Casmurro, Bento Santiago, ex-seminarista, homem maduro e solitário, que habita um simulacro da casa de sua infância e lança um olhar para o passado, buscando compreender o seu ocaso. Dom Casmurro é fio de sua própria meada e Bentinho é uma projeção de si, personagem de ficção de um tratado de persuasão de si e do leitor.

Essa liberdade interpretativa da obra de Shakespeare só é possível graças à narrativa em primeira pessoa, que permite essa série de relatos pessoais ilustrada com recortes da história literária. A memória resgatada é trôpega, imprecisa. Portanto, é necessário preencher as lacunas da memória com as aproximações entre vida e literatura, exercício que estamos sempre fazendo, parte essencial da nossa ligação com nossa realidade assumida. No entanto, a aproximação entre vida e literatura não é um exercício apressado de autor diletante, ela ressalta a bela arquitetura da forma construída por Bento Santiago e acentua a retórica do convencimento. O feliz e apaixonado Bentinho, uma ficção da memória, é fruto da casmurrice do autor.

Podemos mesmo pensar que o paralelismo entre o personagem Bentinho e o autor Dom Casmurro é símile do paralelismo entre experiência subjetiva, a memória resgatada da infância 
feliz, e crítica literária, a reconstrução da memória através da experiência da leitura. Há, penso, dois efeitos que podemos extrair dessa constatação. Primeiro, ela desautoriza o leitor diletante, porque a erudição do narrador se configura também como uma forma de validar e reforçar o discurso e mobiliza o leitor interessado a reconstruir o que foi lido a partir dos seus conhecimentos a respeito da literatura, filosofia, religião etc., em sintonia com a sua visão de mundo e experiência subjetiva. Em ambos os casos, o narrador estará sempre um passo adiante, porque o fato narrado por ele quando da mobilização da fonte literária cria a necessidade de interpretação por parte do leitor - o que não ocorre de imediato: a luz sobre o que foi narrado como crítica literária ficcionalizada se dá na releitura, que se mobiliza indefinidamente porque o narrador, imediatamente após a citação e comentário literário, já repõe o material comentado em novas chaves ao longo da narrativa. Vejamos outro exemplo, nesse pequeno trecho que trata do episódio do dandy do cavalo baio:

[...] Relê Alencar: "Porque um estudante (dizia um dos seus personagens de teatro de 1858) não pode estar sem estas duas cousas, um cavalo e uma namorada." Relê Álvares de Azevedo. Uma das suas poesias é destinada a contar (1851) que residia em Catumbi, e, para ver a namorada no Catete, alugara um cavalo por três mil-réis...Três mil-réis! Tudo se perde na noite dos tempos (ASSIS, 1977d, p. 172).

Embora Machado cite Alencar, a cena remete, de maneira enviesada, a outro autor. Como se sabe, um dos modelos para a literatura de Alencar ${ }^{4}$ é o escritor francês Honoré de Balzac (1799-1850). Em um dos seus mais representativos romances, O Pai Goriot (1834), Rastignac, um jovem estudante arrivista que busca ascender socialmente na Paris de 1819, convive a todo o momento com a falta de dinheiro e o aparelhamento material para alcançar o seu intento. Possuir um cavalo, e uma carruagem, é um dos requisitos básicos não só para a circulação na cidade, mas para o livre trânsito nas grandes casas da aristocracia parisiense. Uma passagem é significativa: Rastignac é convidado a visitar uma senhora da alta sociedade; como tem pouco dinheiro, ele segue a pé, cuidando para não sujar a roupa e, assim, manter a aparência aristocrática; como andava distraído com a ansiedade do encontro, acabou por enlamear-se:

\footnotetext{
- Se eu fosse rico - pensou, ao trocar uma moeda de cem soldos que levava para um caso de necessidade - iria de carro e assim poderia pensar à vontade.

Chegou, finalmente, à rua Helder e perguntou pela Condessa de Restaud. Com a raiva fria dum homem que tem a certeza de que um dia triunfará, recebeu o olhar de desprezo dos criados que o viram atravessar o pátio a pé sem terem ouvido o ruído duma carruagem. E esse olhar o feriu mais profundamente porque, ao entrar no pátio,
}

\footnotetext{
${ }^{4}$ Balzac é um dos modelos adotados por Alencar em seu projeto literário. Sobre o tema, consultar ALENCAR, (1959). 
percebera a sua inferioridade ao ver um belo cavalo atrelado a um desses carros que revelam uma existência dissipadora e atestam o hábito de todas as delícias parisienses (BALZAC, 1949, p. 54).

Recordemos a passagem em Dom Casmurro. O narrador afirma que no tempo de sua mocidade não se podia estar sem cavalo e namorada, ao passo que, em oposição, o narrador de O pai Goriot sugere uma outra vinculação, menos ingênua e potencialmente esclarecedora; possuir um cavalo é um meio de manter as aparências e galgar posições na aristocracia parisiense. Lembremos que Bentinho é representante de uma aristocracia à brasileira, de proprietários, e Capitu, como o narrador sugere ao longo do romance, galga posições na sociedade com seu casamento. Note-se como no romance de Balzac a ascensão se coloca como um meio objetivo dentro da dissimulação, ao passo que Machado, através de um procedimento de ocultação das fontes - Balzac via Alencar - trata da ascensão dissimulando a matéria que trata da dissimulação. Para sugerir a dissimulação de Capitu, o narrador dissimula o intertexto, fazendo da história literária um objeto de análise do processo de deslocamento social.

Está aí, como matéria ficcional, o procedimento de ficção crítica, recurso para completar a elipse que se faz presente entre o texto e o leitor.

\section{Muros, melancolia e exílio}

Se o uso da literatura é um procedimento de caracterização do personagem e agente mobilizador entre leitor e texto ficcional, é a representação das assimetrias sociais por meio de muros, espaços de circulação e sociabilidade que dá a esses personagens a dimensão da especificidade histórica nacional. Em A mão e a luva (1874), segundo romance de Machado, Guiomar é uma jovem órfã de pai "não sei de que repartição do Estado" e mãe "enérgica e resoluta". A jovem, desde cedo, mostrou-se capaz de apreender a sua realidade com inteligência e sensibilidade.

\footnotetext{
$\mathrm{Na}$ idade de dez anos, tinha Guiomar uns desmaios de espírito, uns dias de concentração e mudez, uma seriedade, a princípio intermitente e rara, depois frequente e prolongada, que desdiziam da meninice e faziam crer à mãe que eram prenúncios de que Deus a chamava para si. [...] A primeira vez que esta gravidade da menina lhe tornou mais patente foi uma tarde, em que ela estivera a brincar no quintal da casa. $\mathrm{O}$ muro do fundo tinha uma larga fenda, por onde se via parte da chácara pertencente a uma casa da vizinhança (ASSIS, 1977b, p. 82).
}

O muro que divide classes sociais e visões de mundo distintas é um outro exemplo que gostaria de mencionar. A melancolia de Guiomar é interpretada por sua mãe como prenúncio Revista Graphos, vol. 21, n 2, 2019 | UFPB/PPGL | ISSN 1516-1536 
de morte, enquanto o narrador em terceira pessoa relembra o primeiro "desmaio de espírito" da jovem. O muro que divide sua casa é a representação física da delimitação social tão comum no Brasil. Cercas, muros, grades que protegem e regem o convívio, filtrando de acordo com a necessidade a passagem das classes menos afortunadas.

Penso que a melancolia de Guiomar pode ser compreendida como um sintoma originado do mal-estar no capitalismo à brasileira, cerceador de subjetividades e movido a assimetrias sociais, tal como é formulado pelo psicanalista e professor Christian Dunker. Na prosa machadiana, as delimitações de espaço materializadas por muros, cercas e espaços sociais (a casa de orates em $O$ alienista, a casa da infância de Bentinho, o morro do Castelo, onde são feitas as predições em Esaú e Jacó etc.) configuram-se para o leitor como experiência das assimetrias e subjetividades das diversas camadas sociais brasileiras ficcionalizadas por Machado.

O muro é uma estrutura de defesa, uma forma de determinação do espaço como território. A defesa (Abwehr) é um conceito psicanalítico que gira em torno das diferentes maneiras como indeterminação, gerada pelo desejo, pela angústia, pelo trauma e pela pulsação, pode ser concernidas em estruturas de determinação (DUNKER, 2015, p. 59).

A fenda, como uma janela para outros horizontes, evidencia para Guiomar que os seus pressentimentos eram reais. A pequena passagem atua como gatilho do ensimesmamento, do silêncio, da solidão e da consciência de que há barreiras para a realização de projetos cuja demanda a própria Guiomar criança desconhece. O que é a melancolia na modernidade senão essa forma de sensibilidade conflituosa com os espaços de circulação impostos para o controle? O peso e o contrapeso das existências colocadas em paralelo?

Alguns anos depois, em Dom Casmurro, a melancolia ganha contornos de intervenção concreta. Capitu atua no estado de coisas de modo a burlar certos constrangimentos sociais de classe embutidos na relação entre vizinhos - "a dificuldade estava na casa ao pé, a gente do Pádua.”, anuncia entre sussurros José Dias. Ela atua apesar dos constrangimentos, apropriandose do símbolo da divisão e inscrevendo na materialidade do espaço sua intervenção afetiva. Se Guiomar encontra uma pequena fissura social, Capitu age para que o muro venha abaixo.

\footnotetext{
- Capitu.

- Mamãe!

- Deixa de estar esburacando o muro; vem cá.

[...] Capitu estava ao pé do muro fronteiro, voltada para ele riscando com um prego.

[...] Nisto olhei para o muro, o lugar em que ela estivesse riscando, escrevendo ou
} 
esburacando [...] Vi uns riscos abertos [...] Então quis vê-los de perto, e dei um passo. Capitu agarrou-me, mas, [...] correu adiante e apagou o escrito. [...] Dei um pulo, e antes que ela raspasse o muro, li estes dois nomes, abertos ao prego, e assim dispostos: BENTO

CAPITOLINA (ASSIS, 1977d, p. 84-86).

A cena é polifônica. Enquanto o narrador nos situa quanto ao espaço da ação e descreve Capitu, "as mãos, a despeito de alguns ofícios rudes, eram curadas com amor; não cheiravam a sabões finos nem águas de toucador, mas com água do poço e sabão comum trazia-as sem mácula" (ASSIS, 1977d, p. 85), vemos a jovem progressivamente agindo sobre o muro. O objeto "muro", estrutura de defesa territorial e contenção de pobres, negros e demais "náufragos da existência" sofre intervenção da jovem Capitu, que segundo o narrador é pobre, de mãos rudes, cheira a sabão comum, mas é sem mácula. Note-se, en passant, que a descrição integra a máxima dedicada aos pobres com permissão para transitar do outro lado do muro. São limpos.

É importante salientar como o contexto histórico e social está inserido na metáfora dos muros de Guiomar e Capitu. Em A mão e a luva, o modo de vida advindo do paternalismo e da lógica escravocrata está em segundo plano, sufocado pelo esboço do casamento burguês como meio de ascensão social e as suspeitas, ajustes e constrangimentos que o Sujeito deve fazer e sofrer para atender às suas demandas. Qualquer tipo de superação desse estado de coisas está longe de se concretizar no horizonte ficcional de A mão e a luva.

Quando da publicação de Dom Casmurro, 1889, o país havia derrubado alguns muros do atraso sem, no entanto, agir contra a estrutura que os sustentava. A abolição havia ocorrido em 1888, sem integrar os negros na sociedade, relegando-os à margem do sistema social e econômico. A proclamação da República de 1889 não resultou em políticas públicas e democráticas de inserção da população pobre no mercado de trabalho ou de combate às desigualdades. O Brasil continuou arcaico e agrário. A guerra de Canudos é exemplo importante desse movimento de construção do Brasil moderno e ansioso por ingressar na Belle Époque mundial da virada do século 19 sob os ossos dos miseráveis.

Capitu compreende esta dinâmica. O "cálculo" que lhe acusa o narrador-casmurro na verdade é uma condição essencial de trânsito e sobrevivência no paternalismo. Vejamos mais uma cena.

[...] Nunca a vi tão irritada como então; parecia disposta a dizer tudo a todos. Cerrava os dentes, abanava a cabeça... [...] Capitu refletia. A reflexão não era cousa rara nela, e conheciam-se as ocasiões pelo apertado dos olhos. Pediu-me algumas circunstâncias mais, as próprias palavras de uns e de outros, e o tom delas. [...] Tínhamos chegado à

Revista Graphos, vol. 21, n 2, 2019 | UFPB/PPGL | ISSN 1516-1536 
janela; um preto, que, desde algum tempo, vinha apregoando cocadas, parou em frente e perguntou:

- Sinhazinha, qué cocada hoje?

- Não, respondeu Capitu.

- Cocadinha tá boa.

- Vá-se embora, replicou ela sem rispidez.

[...] não quis saber de doce, e gostava muito de doce (ASSIS, 1977d, p. 93-94).

Capitu toma para si o mundo e o interpreta, colhe informações, pesa consequências, analisa fatos e toma decisões. Uma das conclusões do narrador é de que a vida é uma ópera, em que cada qual na roda do amor e da vida cumpre um papel - "não só pela verossimilhança, que é muita vez, toda a verdade, mas porque a minha vida se casa bem a definição." (ASSIS, 1977d, p. 80). Na concepção de mundo de Bento Santiago, os papéis sociais estão determinados para todos que o cercam. Inclusive ele, que busca substituir o pai no comando da casa e na regência da família e agregados. Capitu, no entanto, é o acorde dissonante que destoa das categorizações impostas pela verossimilhança do narrador. Da "vida é uma ópera" para "a vida é um teatro", outra simetria constante proposta por narradores machadianos, é um salto. Franco Moretti, ao tratar do sentido moderno da tragédia de Shakespeare, explica que

\footnotetext{
A ideia de que o mundo é um teatro onde os homens simplesmente desempenham um papel só tem significado verdadeiro no contexto de uma "sociedade hierárquica feudal", cuja característica fundamental [...] consiste no fato de que "o trabalho produtivo e regulador da sociedade é dividido oficialmente entre grupos, faixas, classes ou pessoas' [...] (MORETTI, 2007, p. 72-73).
}

Se pensarmos nos papéis já previamente fixados na narrativa, veremos que a sociedade brasileira proposta por Dom Casmurro é essencialmente jurídica, católica, masculina, escravista e unifocal, expressando apenas uma visão de mundo, a de Bento Santiago, que, por sua vez, é a extensão da elite brasileira. O ponto essencial para que a argumentação do narrador seja validada é que novamente o leitor é convocado para aceitar ou não as ações da narrativa, aderindo a verossimilhança de Bento Santiago como uma verdade. "O indivíduo existe, portanto, somente enquanto é um ator num papel social" (MORETTI, 2007, p. 72-73).

Prova disso é a continuação da cena, em que ouvimos o canto do vendedor de cocadas. A entoada parece anunciar pelas ruas, tal um gesto lúdico e carnavalesco, que nem todos terão acesso às suas narrativas, verossimilhanças e verdades. "Chora, menina, chora, / Chora, porque não tem /Vintém,". O vendedor de cocadas sobrevive e atua entre a poesia (seu canto) e a violência (a privação da liberdade). $O$ fruto de seu trabalho não lhe pertence, o doce que produz não lhe adoça os sentidos. O gesto reificado que lhe é imposto é partido pelo canto que desperta Revista Graphos, vol. 21, n² 2, 2019 | UFPB/PPGL | ISSN 1516-1536 
Capitu, "usava repeti-la nos nossos jogos da puerícia, rindo saltando, trocando os papéis comigo". A letra da entoada atua como comentário irônico da situação social de Capitu ao mesmo tempo em que o canto sofre da violência epistêmica de tornar-se parte da exploração de seu trabalho, em que mesmo sua subjetividade é coisa, mercadoria. Há uma via de mão dupla própria das contradições da modernidade. O canto-poesia é ao mesmo tempo exercício de subjetividade e performance explorada.

- Se eu fosse rica, você fugia, metia-se no paquete e ia para a Europa.

[...] Como vês, Capitu, aos catorze anos, tinha já ideias atrevidas, muito menos que outras que lhe vieram depois; mas eram só atrevidas em si, na prática faziam hábeis, sinuosas, surdas, e alcançavam o fim proposto, não de salto, mas aos saltinhos (ASSIS, 1977d, p. 94).

A leitura do mundo empreendida por Capitu e sua resolução de alcançar gradativamente os seus objetivos, autonomia em meio ao patriarcalismo, sugere o terreno sensível que a jovem percorre. Afinal, interesse individual pode representar a quebra do "pacto" social entre os diversos atores. Para que o paternalismo funcione, deve-se acreditar nos papéis a se desempenhar, engolindo a indignação. O amor é masculino e burguês, como explica Silviano Santiago, porque significa casar, comprar título de propriedade (SANTIAGO, 2000, p. 31). Não está em jogo nesta matemática o amor fora da instituição casamento ou trânsito por outra forma de realização pessoal que não seja coordenada pelo homem da casa. Daí, a dor de Bento Santiago ao dar-se conta que Capitu ousa sentir e pensar de acordo com suas reflexões e interpretação do mundo, para além do que está orquestrado em sua narrativa paranoica.

E uma vez transposto o muro? Qual o destino das personagens subalternas em ambiente claustrofóbico de suspeita e afetos entrecortados? O salto social implica em certo desterro, solidão e constante vigília.

Os espaços físicos da propriedade obedecem a suas próprias leis. No grande espaço da chácara do Andaraí, local onde se passa a maior parte da ação de Helena, a personagem título é vítima do assédio da família que a recebe e faz uso de subterfúgios e de sua inteligência para visitar o pai biológico e transitar no delimitado espaço patriarcal. Ao final, tomada pelo constrangimento, deixa-se morrer. Lívia, personagem de Ressurreição, frustrada e vencida pelo ciúme de Félix, autoexila-se em sua casa ao final do romance, uma imposição romântica para a sua expiação.

Toda essa morte e exílio deriva do amor enquanto propriedade, cuja maior expressão é o ciúme. Corpos e sujeitos reduzidos a títulos de propriedade. 
Capitu enfrentou o muro físico que a separava da casa de Bentinho e o transpôs, sugerindo, mas não resolvendo, mudanças na lógica apequenada da família patriarcal. No final, desterrada de seu próprio país e local de cultura, é esquecida pelo narrador que reconstrói a casa/muro de sua infância.

[...] fi-la construir de propósito, levado de um desejo tão particular que me vexa imprimi-lo, mas vá lá. Um dia, há bastantes anos, lembrou-me reproduzir no Engenho Novo a casa em que me criei na antiga rua de Matacavalos, dando-lhe o mesmo aspecto e economia daquela outra, que desapareceu (ASSIS, 1977d, p. 68).

$[\ldots]$

Pegamos em nós e fomos para a Europa, não passear, nem ver nada, novo nem velho; paramos na Suíça. Uma professora do Rio Grande, que foi conosco, ficou de companhia a Capitu, ensinando a língua materna a Ezequiel, que aprenderia o resto nas escolas do país. Assim regulada a vida, tornei ao Brasil (ASSIS, 1977d, p. 251).

O tempo, para os desterrados, ora se congela, ora se torna combustível para as desilusões. Todos são leitores, alguns poucos são autores. Aqueles conscientes de que a existência é como um romance fragmentado cujo sentido se perde diante do desejo do outro, ou da suspeita, ou do interesse, impõe sua narrativa aos demais, que são excluídos do jogo. Quando se busca derrubar o muro das assimetrias sociais o resultado é o degredo, a morte, o exílio.

\section{Considerações finais. $E$ bem, e o resto?}

Ao longo desse ensaio, busquei especificar certos temas na série cronológica de romances machadianos. O ciúme, a situação do subalterno, a retórica dos livros e o casamento estão presentes, rearticulados em novas formas e sob novas perspectivas narrativas, em vários romances de Machado de Assis. Algumas imagens são constantes: os muros, os espaços sociais como delimitadores de classe, o exílio. As circunstâncias históricas e sociais, bem como as condições materiais quando da escrita de cada um dos romances, são elementos que condicionam o modo como o romancista trata formalmente esse conteúdo, que dramatiza o ato de exclusão do subalterno e sua sujeição aos modos de expressão patriarcal.

Assim, romances da década de 1870, como Ressurreição, A mão e a luva e Helena, para ficarmos com os exemplos dados ao longo do ensaio, são resultados das condições de produção romanesca enfrentadas por Machado neste período: serialização em folhetins, adequação ao gosto do público leitor em formação, diálogo com a tradição de romances românticos, relativa estabilidade do sistema de produção escravista e patriarcal. Dom Casmurro, por sua vez, apresenta um cenário diverso. Machado está consolidado como o grande autor nacional, o que 
lhe permite a publicação direta em livro, sem a serialização imposta pelo folhetim; o modo de produção escravista e as prerrogativas do senhor como centro do comando patriarcal encontram-se em crise no Brasil do final do século 19. Esses fatores implicam em nova abordagem do gênero romanesco e dos temas machadianos por excelência. A crise testemunhada no livro não arrefece a violência patriarcal, antes a acentua e salienta o ressentimento do patriarca, que agora domina todas as instâncias da ficção. A retórica do narrador quer perfazer o tempo da infância como algo absoluto, mitigado pela perfídia de Capitu. Ao aderir aos argumentos do narrador, o leitor apressado, embebido no ambiente hostil do paternalismo, revela-se parte do sistema ficcionalizado no romance.

Já o leitor atento percebe o lirismo das estratégias de resistência ao patriarcalismo. Anoto uma incômoda frase de Dom Casmurro: "Não houve lepra, mas há febres por todas essas terras humanas, sejam velhas ou novas". Como, nós leitores, podemos naturalizar a morte de um filho, mesmo ilegítimo e ficcional? Acaso aderíssemos ao relato, considerando a verossimilhança proposta pelo narrador, o que justificaria a morte por lepra em um livro que em grande parte celebra o amor juvenil? Isso seria o suficiente para desconfiarmos que não se trata de mera casmurrice do narrador, e sim de um acerto de contas cruel e ardido. O fato de que um sentimento tão íntimo tenha forças tão devastadoras a ponto de aderir a formas de organização social e sintetizar todo um país é um exemplo do poder da linguagem poética de Machado de Assis. Proponho uma breve reflexão um tanto provocativa e certamente provisória acerca do lirismo da prosa machadiana.

Obviamente não sugiro que, do ponto de vista formal, a tensão da prosa machadiana se assemelhe a tensão entre semântica e semiótica, tal como ocorre na poesia enquanto gênero literário, segundo a definição de Valéry e Jakobson, e sintetizada por Agamben na afirmação de que "a poesia não vive senão no contraste" (AGAMBEN, 2002, p. 142). Embora seja fato que, desde o século 19, as fronteiras, cada vez mais invisíveis entre os gêneros, nos permitem intuir o lírico na prosa e em todas as formas de expressão que pretendem singularizar uma experiência, pretendo sugerir um olhar mais fluído da experiência lírica. Na conhecida Palestra sobre lírica e sociedade, Adorno argumenta que

[...] a exigência feita à lírica, a exigência da palavra virginal, é em si mesma social. Implica, portanto, o protesto contra uma situação social que todo indivíduo experimenta como hostil, alienada, fria e opressiva, uma situação que se imprime em negativo na configuração lírica: quanto mais essa situação pesa sobre ela, mais inflexivelmente essa configuração resiste, não se curvando a nada de heterônimo e constituindo-se inteiramente segundo suas próprias leis (ADORNO, 2008, p. 69). 
O romance machadiano, como, via de regra, todo o romance cuja construção de sentido exige participação constante do leitor em busca de interpretação, solicita o mesmo tipo de disposição crítica encontrada na lírica moderna concebida por Adorno. A voz narrativa que se coloca acima das demais no romance machadiano pode ser compreendida como a voz alienante que sufoca o lirismo que resiste, intermitente, e se coloca contra "a prepotência das coisas" como forma de reação à coisificação do mundo patriarcal. Ao identificarmos as metáforas do muro, das exceções e meios de controle do patriarcalismo à ascensão dos subalternos no romance machadiano, estamos identificando os momentos de fratura, em que um "eu", historicamente colocado, se posiciona criticamente contra o estado de exceção aceito e determinado pelo patriarcalismo. Guiomar, Helena e Capitu, penso, são os exemplos dessa lírica expressa pela interpretação miúda, do detalhe. O lírico emerge quando identificamos a voz subalterna que, mediada pelo narrador, busca autonomia. Esta observação aproxima-se do que Adorno expõe sobre a urgência de interpretação da obra de arte.

[...] o que não entendes tu também não possuis, não vale somente para o relacionamento estético com obras de arte, vale também para a teoria estética: nada que não esteja nas obras, em sua forma específica, legitima a decisão quanto àquilo que seu teor, o que foi poeticamente condensado, representa em termos sociais. Determiná-lo requer, sem dúvida, não só o saber da obra de arte por dentro, como também o da sociedade fora dela (ADORNO, 2008, p. 67-68).

A poesia resulta do olhar interpretativo e dialético da obra de arte. Da singularização da linguagem e expressão de um discurso que não pode ser enunciado de outro modo. Creio que Capitu indica que viver à margem, entre muros, implica em adotar técnicas de resistência e nunca perder de vista o fato de que muitas vezes se é exilado em seu próprio país. Capitu é resistência. E resistência é poesia.

\section{Referências}

ADORNO, Theodor W. Palestra sobre lírica e sociedade. In: Notas de literatura I. São Paulo: Duas Cidades / Editora 34, 2008.

AGAMBEN, Giorgio. O fim do poema. Tradução de Sérgio Alcides. Revista Cacto, $\mathrm{n}^{\circ} 1$, agosto de 2002, p. 142-149.

ALENCAR, José de. Como e porque sou romancista. In: Alencar, José de. Ficção Completa. São Paulo: Companhia Aguiar Editora, 1959, vol. I. 
ASSIS, Machado de. Ressurreição. Rio de Janeiro: Civilização Brasileira/MEC, 1977a. A mão e a luva. Rio de Janeiro: Civilização Brasileira/MEC, 1977b.

Helena. Rio de Janeiro: Civilização Brasileira/MEC, 1977c.

Dom Casmurro. Rio de Janeiro: Civilização Brasileira/MEC, 1977d.

BALZAC, Honoré de. O pai Goriot. Tradução de Gomes da Silveira. In: A comédia humana. Introduções, notas e orientação de Paulo Rónai. Vol IV. Porto Alegre: Editora Globo, 1949.

BAPTISTA, Abel Barros. A formação do nome. Duas interrogações sobre Machado de Assis. Campinas: Unicamp, 2003.

Autobibliografias. A solicitação do livro na ficção de Machado de Assis. Campinas: Unicamp, 2003.

CALDWELL, Helen. O Otelo brasileiro de Machado de Assis. São Paulo: Ateliê Editorial, 2002.

DUNKER, Christian Ingo Lenz. Mal-estar, sofrimento e sintoma. Uma psicopatologia do Brasil entre muros. São Paulo: Boitempo, 2015.

KLEIN, Melanie. Inveja e gratidão - um estudo das fontes inconscientes. Rio de Janeiro: Imago, 1984.

MORETTI, Franco. A forma trágica como desconsagração da soberania. In: Signos e estilos da modernidade. Ensaio sobre a sociologia das formas literárias. Tradução de Maria Beatriz Medina. Rio de Janeiro: Civilização Brasileira, 2007.

SANTIAGO, Silviano. Retórica da verossimilhança. In: Uma literatura nos trópicos. Rio de Janeiro: Rocco, 2000.

SANTOS. Rogério Fernandes. O reflexo de Helena. Modelos Literários e nacionalidade em Helena (1876), de Machado de Assis. Dissertação de mestrado. São Paulo: FFLCH/USP, 2009.

SCHWARZ, Roberto. Duas meninas. São Paulo: Companhia das letras, 1997.

Recebido em: 30/09/2019

Aceito para publicação em: 20/11/2019 